\title{
ADMINISTRATIVE AND LEGAL PRINCIPLES OF THE FUNCTIONING OF THE FINANCIAL SYSTEM IN UKRAINE AND EUROPEAN COUNTRIES: A COMPARATIVE ANALYSIS
}

\author{
Andrii Holovach ${ }^{1}$ \\ Donetsk University of Economics and Law, Ukraine \\ Andrii Petrovskyi² \\ National Academy of Internal Affairs of Ukraine, Ukraine \\ Oksana Adamchuk ${ }^{3}$ \\ Vinnytsya National Pirogov Memorial Medical University, Ukraine
}

\begin{abstract}
The purpose of the article is a comparative analysis of administrative and legal principles of the functioning of Ukrainian and European countries' financial systems and further determination of ways to improve domestic legislation in this area. The subject of the study is the experience of European countries in state regulation of financial systems. Methodology. The research is based on a comparison of foreign experience in the legal regulation of the financial system using the example of European countries with current state regulation of the financial system in Ukraine. Due to the used arsenal of general scientific and special-scientific methods and techniques of scientific knowledge, the content of administrative and legal principles of the functioning of the national financial system in conditions of liberalization of foreign economic relations, strengthening of integration and globalization processes in international financial and commodity markets was characterized and determined. The results of the comparative legal study revealed the absence of a general model of the financial system state regulation in Ukraine; rather, the presence of administrative and legal framework for the provision of financial sector's certain components, in particular, banking, investment, tax and budget, financial services market, etc. Practical implications. Administrative and legal principles of the financial system functioning in certain European countries expose greater effectiveness of the financial system state regulation in comparison with Ukraine. Most European states support the policy of regulating the financial system as a holistic, indivisible phenomenon, gradually shifting away from its interpretation as a set of separate segments. On this issue, significant influence has been made by the European Union, which introduced integration of the most important functions in the regulation of the EU financial system and assigning these functions to a separate group of special bodies. It is expedient to include this experience in the legal system of Ukraine in order to increase its economic stability. Relevance/originality. A comparative legal study of world experience in the administrative and legal regulation of the financial system functioning in Ukraine and European countries provides a better understanding of prospects for development of national administrative legislation in this area.
\end{abstract}

Key words: administrative and legal principles, financial system, state regulation.

JEL Classification: D73, P43, H83

\section{The relevance of the topic}

The vital activity of any state depends on the functioning of a large number of different elements, such as the society, legal system, security and inviolability of its territories, etc. One of the most important components is the economy of the country. In Ukraine, the financial sector is at a transitional stage now due to a number of factors: first, Ukrainian state is relatively young compared to other European countries; second, a rapid shift of the national economy from a planned to market form; third, the restructuring of regulatory framework and state policy transformation in economics under the "pressure" of European standards. Moreover, some incompleteness and shortcomings of the financial

\footnotetext{
Corresponding author:

${ }^{1}$ Department of State-Legal, Administrative-Legal, and Criminal-Legal Disciplines, Donetsk University of Economics and Law.

${ }^{2}$ Department of Civil Law and Procedure, National Academy of Internal Affairs of Ukraine.

${ }^{3}$ Department of Anatomical Pathology, Forensic Medicine and Law, Vinnytsya National Pirogov Memorial Medical University.
} 
system of Ukraine need further reformation and development. Thus, the issue of a state influence on the financial sphere, that is, its state regulation, is important. In this case, relations, which occur, are regulated by rules of many branches of law. Hence, in the modern legal system of the state, there are corresponding administrative and legal principles of the functioning of the financial system of Ukraine. It is appropriate to note that this aspect is not a novel in foreign countries. In particular, in each European country, there are a certain authority and legal principles of support and influence on the financial sector that are relevant to follow.

It should be emphasized that in the scientific sphere, the question of comparing the administrative and legal principles of the functioning of the financial system of Ukraine and European countries was not properly addressed. Moreover, the lack of theoretical and practical justification of this aspect confirms the high level of its relevance. A comparative analysis of the administrative and the legal framework for the functioning of the financial system in European countries and Ukraine enables to find positive and negative factors of activity in this area, as well as to understand what experience should be applied.

\section{Past research review}

The financial system is a multidimensional phenomenon, therefore, a large number of foreign and domestic scientists of various scientific fields research it, in particular: Voronova L.K., Oparin V.M., Borynets SYa., Afanasiev M.P., Vasylyk O.D., Lunina I.O, Sadovskyi V.M., Mikhailov A.M., and others. The issues of the administrative and legal mechanism of the financial system regulation were considered in works by such theoreticians as: Bandurka O.M., Averianov V.B., Zasunko S.S., Kolpakov V.K., Stolbovyi V.P., Sushchenko V.D., and others. Foreign experience of state regulation of financial systems was highlighted in works of W. McDonald, T. Rose, D. Trachtman, and others. Instead, a comparative analysis of Ukrainian and foreign administrative principles in ensuring the financial system functioning has not been properly carried out.

The purpose of the article is to conduct a comparative analysis of administrative and legal principles of the functioning of the financial system in Ukraine and European countries.

To reveal this problem, first, it is necessary to outline the features and define the content of categories "administrative and legal principles" and "financial system" as separate phenomena. It should be noted that the concept of "administrative and legal principles" is quite common in the scientific literature. In addition, it consists of two independent terms that have a broad content. Thus, in accordance with provisions of the dictionary, "administration" is revealed as a bureaucratic management by means of orders and directives (Busel, 2005). In turn, the word "principles" is used as:

- the basis of something;

- the main thing, on which something is based, established;

- the initial, main position, principle; the basis of the outlook, the rule of conduct;

- the way, method of doing something (Bilodid, Buriachok, 1972; Zabroda, 2013).

Therefore, administrative principles can be defined as the bases, priorities of public administrating. Moreover, the term "legal" denotes their connection with a particular branch of law, that is, administrative. The latter is considered by scholars as a set of legal norms, which regulate public relations of managerial nature in order to fulfil the tasks and functions of the state, and which appear in executive power, the internal organization of other state bodies, as well as in carrying out external legal authorities by public organizations and their bodies (Alforov, Vashchenko, Dolgopolova, Kupin, 2011; Administratyvne pravo Ukrainy, 2000). From this perspective, Melnik R.S. and Bevzenko V.M. argue that administrative law regulates such groups of social relations as:

- social relations that arise out of human and civil rights and freedoms provision by the subjects of public authority, primarily public administration;

- social relations in public administration of a state and communal property objects;

- social relations in the internal organization of public authorities;

- public relations in the interaction of public authorities with civil society institutions (Melnyk, Bevzenko, 2014).

Therefore, administrative and legal principles can be defined as codified bases of state bodies' authority, concerning public administration in certain spheres of social relations. Considering this interpretation, the administrative and legal principles are not separate principles of the work of certain state bodies, but a set of rules of law, which contain provisions of initial, key ideas of management in a certain field of social relations. In the present research, such a sphere is the financial system, the content of which also needs further elaboration.

It should be emphasized that the main feature of the financial system is its systemic nature, that is, the presence of the structure of interconnected elements. The idea of a system as a special form of unity of categories dates back to ancient Greece (Agoshkova, Ahlibininskiy, 1998; Bilinskyi, 2011). It is characteristic that each element is a completely independent category, which can have its own purpose of existence, task, etc. However, together such elements acquire common features, and their target orientation may change. In this regard, a logical question arises, what the financial system represents and what elements compose it? There 
are several scientific views on defining the content of this category. For example, Oparin V.M. argues that the issue of defining the content of the financial system should be considered from two perspectives: the substantive content and the institutional structure. Under the substantive content of the financial system, a set of separated but interrelated units (finance of business entities, state (public finance), international finance, financial and insurance market), which reflect the particular forms of financial relations, is meant. According to institutional structure, the financial system is a set of financial institutions that ensure its effective functioning, organization and implementation of financial activities of its subjects (Bubryka, Solonar, Utkina, 2016; Oparin, 2006). Kirilenko considers the financial system as a set of separate areas of financial relations, which are interconnected and have centralized or decentralized funds of money, as well as an appropriate management apparatus and legal support (Kyrylenko, 2002). According to Popov, the financial system is a set of historical economic relations as for the formation, distribution, and use of funds of money of the state, economic entities, and households, distribution and redistribution of GDP, which are realized by means of a financial body in accordance with the state financial legislation (Popov, 2012; Ganzitska, 2016). According to Orliuk, the category of the financial system has multidimensional nature, that is, its content can be defined in three "dimensions", namely:

- as a set of financial institutions that contribute to the creation and use of funds specifically for the financial performance of the state;

- as a set of state authorities and bodies of local government, which carry out the management of financial activity of the state as a whole, as well as enterprises, institutions, and organizations, which participate in it;

- as a set of public finances, finances of business entities, international finance and the financial market (Orliuk, 2010; Myrhorod-Karpova, 2017).

Considering the diversity of approaches, it can be concluded that the financial system of a state is a set of social relations that arise in the distribution and use of entire monetary resources, are implemented in the activities of individual entities and provided by the state, which determines the features, forms, and procedure for conducting financial activities. Agreeing with the scientific position of Nesterenko, it should be noted that these relations are consolidated into integral institutions, which, in turn, are a part of the financial system structure. For that reason, the latter includes public finances, finances of business entities, international finance and financial markets (Nesterenko, 2013). Moreover, financial markets include banking, tax and budget, investment, financial services markets, etc.

Therefore, after outlining the essence and features of all the necessary concepts, it is possible to determine what constitutes the administrative and legal principles for the functioning of the state financial system. In this research, these principles are considered as a set of legal norms that establish the key principles of management activities of state authorities in the field of organization and provision of the financial system as a set of relations regarding the distribution and use of monetary resources. In other words, these principles regulate the features of the existing model of state and legal regulation of the financial system as a whole.

The administrative and legal principles of the financial system functioning can be found in the provisions of many legislative and subordinate regulatory legal acts of Ukraine. For example, in the Law of Ukraine "On Financial Services and State Regulation of Financial Services Markets", Article 20 states that state regulation of financial service activities is carried out through:

1) running the State Registers of financial institutions and the registers of individuals, who are not financial institutions, but have the right to provide certain financial services and licensing of financial services;

2) legal regulation of financial institutions;

3) supervision over financial services market participants (except for financial services customers);

4) application of coercive measures by the authorized state bodies;

5 ) other measures on state regulation of financial services markets (Pro finansovi posluhy ta derzhavne rehuliuvannia rynkiv finansovykh posluh).

Moreover, similar provisions are contained in the Law of Ukraine "On Investment Activity". Chapter III of the Law defines the purposes, forms, and limits of legal state regulation of investment activity. Specifically, its purpose determines implementation of economic, social, scientific and technical policies based on the goals and indicators of economic and social development of Ukraine, state and regional programs of economic development, state and local budgets, in particular, the amount of their investment activities provided for by them. Simultaneously, privileged conditions are created for investors investing in the most important areas for meeting social needs, first, in the social sphere, technical and technological improvement of production, creation of new workplaces for citizens, who need social protection, introduction of discoveries and inventions in the agriculture, in the implementation of programs for the consequences of the Chernobyl accident elimination, in the production of building materials, in education, culture, protection of cultural heritage, environmental protection and health (Pro investytsiinu diyalnist). Under these conditions, the main forms of the state regulation of investment activities are public investment management, regulation of investment activity, control over the implementation of investment activities by its participants and investors (Pro investytsiinu diyalnist). 
In banking, state regulation is limited. According to Articles 4 and 5 of the Law of Ukraine "On Banks and Banking Activities", banks, formed in accordance with the laws of the state, determine independently directions of their activity and specialization by types of services. Public authorities and local governments are prohibited from influencing management or employees of banks in the course of their duties or interfering in bank activities (Pro banky i bankivsku diialnist). Instead, in accordance with the legislation, the National Bank of Ukraine, a special central state authority, regulates banking activities, as well as supervises over the banking system in order to promote financial stability within powers provided by law (Pro banky i bankivsku diialnist; Pro Natsionalnyi bank Ukrainy). Forms of administrative and legal influence on the banking system are also defined legally:

1) registration of banks and licensing of their activities; 2) establishment of requirements and restrictions on the activities of banks;

3) application of sanctions of administrative or financial nature;

4) supervision over the activities of banks;

5) provision of recommendations on the activities of banks (Pro banky i bankivsku diialnist).

It is worth noting that in state regulation of fiscal and tax relations, the administrative and legal principles of the financial system functioning demonstrate the change in the vector of public administration in this field due to its reformation. Confirmation of this fact can be found in the provisions of the Strategy of Sustainable Development "Ukraine 2020" approved by the Decree of the President of Ukraine dated January 12, 2015. Paragraph seven of the document states that the purpose of the tax reform is to form a tax system, which is simple, economically fair, with minimal time spent on the calculation and payment of taxes, able to create necessary conditions for sustainable development of the national economy, and provide sufficient coverage of the State Budget of Ukraine and local budgets. The main areas of the reform are transition from supervisory and punitive functions of fiscal authorities to servicing that helps in the calculation and execution of tax payments, rather than is aimed at filling the budget through financial sanctions and overpayments; reduction of the number of taxes and their size, as well as simplification of the procedure of calculation and payment; introduction of electronic services for taxpayers; reduction of tax burden on wages in order to take them out of shadow; improvement of Ukrainian legislation aimed at the reinforcement of combating tax evasion schemes for both legal entities and natural persons, in particular, improving the administration of value added tax, creating a system of tax control according to the degree of risk in the activity of taxpayers, ensuring openness of access to payment information taxes, improving legislation on transfer pricing issues, implementation of control over expenditures of individuals (Pro Stratehiiu staloho rozvytku «Ukraina-2020»).

Therefore, the analysis of current legislation has shown that at present, there are a large number of administrative and legal principles for the financial system functioning, which are provided for in legal rules that regulate key aspects of state influence on certain spheres of the financial system's components. Moreover, the conducted research revealed that a general model of the financial system state regulation is not developed in Ukraine. There are only administrative and legal principles for providing certain components of the financial sector, in particular, banking, investment, tax and budget, financial services markets, etc. In these areas of state regulation, independent political courses are formed; therefore the general inconsistency of administrative and legal regulation of the financial system is evident. Due to this, in Ukraine, a large number of state authorities with different powers in the financial sphere exist. At present, the financial system is coordinated by the Cabinet of Ministers of Ukraine, the Verkhovna Rada of Ukraine, the Accounting Chamber, the President of Ukraine, the Ministry of Finance of Ukraine, the State Treasury, the National Bank, fiscal authorities, etc. Such a control and regulation mechanism is extremely cumbersome and ineffective, which ultimately leads to negative economic consequences for our country.

European experience of administrative regulation of the financial systems and financial activities differs significantly. It is worth noting that the features of the current stage of the world economic development are the liberalization of foreign economic relations, strengthening of integration and globalization processes in the international financial and commodity markets, which is due to the openness of national economies and cooperation of countries in various spheres of economic activity. Thus, the openness of the national economy contributes to the development and improvement of economic, productive, financial, social, cultural, and other interrelationships between countries (Denysiuk, 2015). A remarkable example of this fact is the European Union (hereinafter - the EU). The main thing is that a large number of states are now a part of the EU. This international organization, represented by a special body, coordinates the functioning of financial systems of the Member States to ensure economic stability in the EU. In addition, such an approach does not preclude the existence of appropriate national mechanisms to maintain the functionality of financial systems in the very Member States.

A key difference in the regulation of financial systems in European countries is in perceiving the role of the state in this process and the content of the financial system as a whole. Financial consolidation and formation of large financial conglomerates demand replacement of a traditional regulatory paradigm based on consideration of the financial system as a set of segregated segments 
(insurance, banking, stock, etc.) for one that takes into account the interconnectivity of different financial intermediaries and establishes for them the same rules and supervision principles. For example, on this basis in the European Union, a new European system of financial supervision has been created, the key institutions of which have become the European Systemic Risk Board and established by the European Commission's proposal three sectoral bodies:

1) European Securities and Markets Authority;

2) European Banking Authority;

3) European Insurance and Occupational Pensions Authority (Giorgio, Di G., Carmine Di Noia, 2005; The Level 3 Committees welcome the new institutional arrangements on European financial supervision; Baldych, 2013).

At the national level, in economically advanced countries, the financial system regulation is also based on consolidation of a large amount of authority within one or more core bodies that implement a common economic policy, which affects all spheres and components of the financial system. Administrative regulation of the financial system in the territory of this state is carried out by a single, key institution, the Treasury (Harust, Tolkachov, 2017). It should be noted that the State Treasury of Great Britain is one of the oldest state agencies, but in terms of numbers, it is one of the smallest. The Treasury is a political and creative department with several functions that link it with the public and industry. It is connected with financial markets mainly through the Bank of England. Historically, its main function was to control public funds spending, but now it is responsible for management of British economy so as to achieve the economic goals set by the ministries and agreed with the Parliament (Yurii, Stoian, Mats, 2002; Bulhakova, Kolodii, 2002). The Treasury of Great Britain has a wide range of functions in support of the financial system. In particular, this authority regulates issues related to:

1) public spending, which includes departmental spending on labour costs and pensions in the public sector, as well as an investment;

2) oversight of the financial services market;

3) strategic oversight of the UK tax system;

4) supervision of economic stability (United Kingdom Government: HM Treasury).

In addition, in accordance with British law, among the main functions of the Treasury is development, preparation, and execution of the state budget; development and execution of the state fiscal policy; tax system management; management of the structural units of the Treasury; development of tax legislation, simplification and computerization of tax legislation; financial and economic forecasting; planning and control over public spending, maintaining budget balance, timely and efficient budget coordination, preparing a financial and budget report, and submitting it to Parliament; realization of the policy of relations with the European Community, maintenance of the balance of profits and expenses related to EU membership, etc. (Havrylishyn, Kozyrieva, 2007).

The German model of administrative regulation of the financial system is similar to British one because it is also based on the unification of powers within the framework of several main bodies of financial coordination. On the territory of Germany, the Federal Financial Supervision Authority carries out oversight functions in the financial sector. This body has a wide range of authorities and has the right to issue sub-normative acts and regulations within the limits of its competence. In addition, the Authority also carries out banking supervision together with the German Federal Bank. The latter, in the process of ongoing control, assesses documents, reports, annual financial statements and audit conclusions, and so on. It should be noted that the Federal Financial Supervision Authority issues licenses for banking, insurance, and financial services, as well as oversees credit institutions, financial conglomerates, insurers, investment and pension funds and securities market (Horuzhii, 2016).

Similar administrative and legal principles of the financial system functioning exist in other European countries as well. In particular, in Poland, the Polish Financial Oversight Commission carries out state financial regulation. This is a body of financial supervision with an autonomous competence and a separate budget that oversees banks, insurance companies, insurance intermediaries, investment companies, asset management companies, investment and pension funds, providers of payment services and electronic money, credit bureaus and securities markets (Horuzhii, 2016). In Sweden, the state regulation of the financial system is implemented by the Financial Supervision Authority. It is a public institution responsible for financial oversight of banks, money, payment institutions, the securities market (including exchanges, clearinghouses), investment and pension funds, consumer lending services, savings and loan associations, as well as insurance and insurance intermediation activities. It is funded at the expense of annual regulatory fees and at the expense of license fees. The agency is subject to the Ministry of Finance of Sweden (Horuzhii, 2016).

The principles of administrative regulation of the financial system of Spain, the most priority areas of which are fiscal, banking, and financial markets, are quite interesting. State regulation of the tax sector is characterized by a high level of efficiency due to numerous reforms in the 80 years of the twentieth century. In order to simplify the procedure for paying taxes, improve taxpayer accounting, and strengthen combat against tax crimes, the reorganization of the tax service was carried out through a series of organizational measures, in particular:

- introduction of identification numbers for all taxpayers, both for legal entities and for individuals; 
- the introduction of tax labels, which contains all the information on a taxpayer: the identification number, all types of taxes payable by a taxpayer, payment deadlines (issued to legal entities at registration, and sent by mail to individuals);

- introduction of mandatory submission of a tax return together with tax labels;

- introduction of tax vectors and memos, in which taxes are defined and their payment periods are determined;

- establishment of close cooperation with banking institutions and structures;

- change in the organizational structure of tax management and the tax service in general (Stukalo, Litvin, Derkach, 2014).

To support the stock market, the National Stock Market Commission monitors the proper functioning of the system, checks Spanish securities markets and activities of all participating organizations. In addition, the Commission also monitors the transparency of the Spanish stock markets and the correct pricing, protects investors. The activity of this body concerns companies that issue securities for public placement, secondary stock markets and companies offering investment services (Stukalo, Litvin, Derkach, 2014).

Although the banking system of Spain is a set of different government agencies and private banking institutions, it is based on principles of strict centralization. In particular, the Bank of Spain, the central bank of the country, is the main institution that regulates the banking system and implements monetary policy in the country. The Bank of Spain is subordinated to the Ministry of Economy and Finance, to which the government delegates powers in the field of monetary policy. The Ministry of Economy and Finance develops provisions for the Bank of Spain to follow when implementing the monetary and credit policy of the Government, defines the principles of the Bank's disciplinary and control functions, establishes the procedure for the Bank to carry out operations with private banks, etc. (Stukalo, Litvin, Derkach, 2014; Rudenko, Tokar, 2010).

\section{Conclusions}

Therefore, the comparative analysis showed that the administrative and legal principles of Ukrainian financial system functioning differ significantly from European ones, which is manifested in the features of state regulation of the financial sphere, in general, and its separate components, in particular. For that reason, the present research enables to conclude the following.

1. The existing administrative and legal principles of Ukrainian financial system functioning are characterized by general inconsistency. In other words, they are disconnected that prevents the creation of a general financial policy in our country and its further realization. In all cases, the administrative and legal principles provided for in the norms of legislative and subordinate acts relate to state regulation in certain spheres of the financial system's constituent elements.

2. The absence of a single legal basis for the national financial system state regulation in practice leads to engagement of a large number of various state bodies, whose powers, in some cases, are repeated causing controversy. This negative aspect has a direct impact on the efficiency of financial activities and the development of the national economy.

3. Analysis of foreign experience has shown that most European states support the policy of regulating the financial system as a holistic, indivisible phenomenon, gradually shifting away from its perception as a set of separate segments. A significant influence on this issue has been made by the European Union, which introduced integration of the most important functions in the regulation of the EU financial system and assigning these functions to a separate group of special bodies.

4. It has been determined that nowadays the financial system state regulation of many European countries is based on consolidation of coordinating and supervisory functions. One or several clearly defined bodies carry out the national regulation of financial relations in European countries such as Germany, Poland, Sweden, Spain, etc. In the UK, the many years' experience is outstanding. In this country, the Treasury is a single body, which is in charge of the regulation of the financial system of the country. This organization works today quite effectively, which is confirmed by the fact that the UK economy is one of the most developed in the world.

Therefore, in some European countries, the administrative and legal principles of financial system functioning reveal the greater effectiveness of the financial system state regulation in comparison with Ukraine. Thus, the given foreign experience should be included in the legal system of our state in order to increase its economic stability.

\section{References:}

Busel, V. T. (2005). Velykyi tlumachnyi slovnyk suchasnoi ukrainskoi movy [Great explanatory dictionary of modern Ukrainian language]. Irpin: ATP "Perun", 1728 p. (in Ukrainian)

Bilodid, I. K., Buriachok, A. A. (1972). Slovnyk ukrayinskoi movy v 11 tomakh [Ukrainian language dictionary (Vols. 1-11)], 3. K. (in Ukrainian)

Zabroda, D. G. (2013). Administratyvno-pravovi zasady: sutnist ta zmist katehorii [Administrative and legal principles: the essence and content of the category]. Administratyvne pravo i protses. [Administrative Law and Process]. 2(4), 45-51. (in Ukrainian) 
Alforov, S. M., Vashchenko, S. V., Dolgopolova, M. M., Kupin, A. P. (2011). Administratyvne pravo. Zahalna chastyna: navchalnyi posibnyk [Administrative Law. General part: teaching manual]. Center for Educational Literature, 216 p. (in Ukrainian)

Administratyvne pravo Ukrainy: pidruchnyk dlia yurydychnykh vuziv i fak. [Administrative Law of Ukraine: a teaching manual for law schools and faculties]. (2000). Yu. P. Bytiak, V. V. Bohutskyi, V. M. Harashchuk et al. (Eds.). Kh., 520 p. (in Ukrainian)

Melnyk, R. S., Bevzenko, V. M. (2014). Zahalne administratyvne pravo: navchalnyi posibnyk [General Administrative Law: teaching manual]. K.: Vaite, 376 p. (in Ukrainian)

Agoshkova, Ye. B., Ahlibininskiy, B. V. (1998). Evoliutsia poniatia sistemy [Evolution of the concept of system]. Voprosy filosofii [Questions of Philosophy], 7, 170-179. (in Russian)

Bilinskyi, D.O. (2011). Pro finansy yak systemne ponyattia [On Finance as a System Concept]. Pravo i suspilstvo [Law and Society], 4, 55-59. (in Ukrainian)

Bubryka, M. M., Solonar, A. V., Utkina, M. S. (2016). Pidkhody do vyznachennia ponyattia «finansova systema» v Ukraini ta zarubizhnykh krainakh [Approaches to the definition of "financial system" in Ukraine and foreign countries]. Pravo i suspilstvo [Law and Society], 4(2), 159-164. (in Ukrainian)

Oparin, V.M. (2006). Finansova systema Ukrainy: avtoreferat [The financial system of Ukraine: the author's abstract]. KNEU named after Vadym Hetman, 33 p. (in Ukrainian)

Kyrylenko, O.P. (2002). Finansy (teoriia i vitchyzniana praktyka): navchalnyi posibnyk [Finance (theory and domestic practice): teaching manual]. Ternopil: Aston, 212 p. (in Ukrainian)

Popov, I. V. (2012). Problemni aspekty zabezpechennia stabilnosti finansovoi systemy Ukrainy [Problematic aspects of ensuring the stability of the financial system of Ukraine]. Ivestytsii: praktyka ta dosvid [Investitions: Practice and Experience], 11,77-80. (in Ukrainian)

Ganzitska, T.S. (2016). Suchasne rozuminnia poniattia ta struktury finansovoi systemy [Modern understanding of the concept and structure of the financial system]. Yurydychnyi naukovyi elektronnyi zhurnal [Juridical Scientific Electronic Journal], 5, 48-50. (in Ukrainian)

Orliuk, O. (2010). Finansove pravo. Akademichnyi kurs: pidruchnyk [Financial Law. Academic course: teaching manual]. K.: Yurinkom Inter, 808 p. (in Ukrainian)

Myrhorod-Karpova, V. (2017). Porivnyalno-pravovyi analiz katehorii «finansova systema» u rozrobkakh vitchyznianykh ta zakhidnykh naukovtsiv [Comparative and legal analysis of the category "financial system" in the development of domestic and western scholars]. Natsyonalnyi yurydycheskii zhurnal: teoria i praktyka [National Legal Journal: Theory and Practice], 70-73. (in Ukrainian)

Nesterenko, A.S. (2013).Vyznachennia «finansovoi systemy» ta yii strukturnyi sklad [Definition of "financial system" and its structure]. Naukovyi visnyk Mizhnarodnoho humanitarnoho universytetu [Scientific Bulletin of the International Humanitarian University], 6-3 (1), 72-75. (in Ukrainian)

Pro finansovi posluhy ta derzhavne rehuliuvannia rynkiv finansovykh posluh: zakon vid 12.07.2001 №2664-III [On Financial Services and State Regulation of Financial Services Markets: Law No. 2664-III of 12.07.2001]. Vidomosti Verkhovnoi Rady Ukrainy [Bulletin of the Verkhovna Rada of Ukraine]. (2002). No. 1, Art. 1. (in Ukrainian)

Pro investytsiinu diyalnist: zakon vid 18.09.1991 №1560-XII [On Investment Activity: Law of 18.09.1991 No. 1560-XII]. Vidomosti Verkhovnoi Rady Ukrainy [Bulletin of the Verkhovna Rada of Ukraine]. (1991). No. 47, Art. 646. (in Ukrainian)

Pro Stratehiiu staloho rozvytku «Ukraina-2020»: ukaz vid 12.01.2015 №5/2015 [On the Strategy of Sustainable Development "Ukraine-2020": Decree dated January 12, 2015 № 5/2015]. Ofitsiinyi visnyk Ukrainy [Official Bulletin of Ukraine]. (2015). No. 4, Art. 67. (in Ukrainian)

Pro banky i bankivsku diialnist: zakon vid 07.12.2000 №2121-III [On Banks and Banking: Law dated December 12, 2000 No. 2121-III]. Vidomosti Verkhovnoi Rady Ukrainy [Bulletin of the Verkhovna Rada of Ukraine]. (2001). No. 5, Art. 30. (in Ukrainian)

Pro Natsionalnyi bank Ukrainy: zakon vid 20.05.1999 №679-KHIV [On the National Bank of Ukraine: Law of May 20, 1999 No. 679-XIV]. Vidomosti Verkhovnoi Rady Ukrainy [Bulletin of the Verkhovna Rada of Ukraine]. (1999). No. 29, Art. 238. (in Ukrainian)

Denysiuk, O.V. (2015). Mekhanizmy derzhavnoho rehuliuvannia finansovoi sfery ekonomiky krainy: analiz zarubizhnoho dosvidu [Mechanisms of state regulation of the financial sphere of the country's economy: analysis of foreign experience]. Derzhavne budivnytstvo [State Construction], 1, 1-8. (in Ukrainian)

Giorgio, Di G., Carmine Di Noia. (2005). Towards a new architecture for financial regulation and supervision in Europe: an updated, reduced, synthesis of previous research. Journal of financial transformation, 14, 145-156.

The Level 3 Committees welcome the new institutional arrangements on European financial supervision: Pressrelease / Committee of European Securities Regulators, Committee of European Banking Supervisors, Committee of European Insurance and Occupational Pensions Supervisors, 23 September 2009. Retrieved from http://www.esma.europa.eu/system/files/3L3_press_release_EC_Communication_23_September_2009.pdf. 
Baldych N. (2013). Instytutsiini osnovy yevropeiskoi systemy rehuliuvannia ta nahliadu za finansovymy rynkamy [Institutional framework of the European system of regulation and supervision of financial markets]. Visnyk Natsionalnoi akademii derzhavnoho upravlinnia [Bulletin of the National Academy of Public Administration], 148-155. (in Ukrainian)

Harust Yu. V., Tolkachov B. O. (2017). Porivnialna kharakterystyka finansovykh system Velykobrytanii ta Ukrainy [Comparative characteristic of the financial systems of Great Britain and Ukraine]. Forum prava [Forum of Law], 1, 5-9. (in Ukrainian)

Yurii, S. I., Stoian, V. I., Mats, M. Y. (2002). Kaznacheiska systema: pidruchnyk [Treasury system: textbook]. Ternopil: Kart-blanky, 82 p. (in Ukrainian)

Bulhakova, S. O., Kolodii, O. H. (2002). Istoriia kaznacheiskoi spravy: Navch. posibnyk [History of Treasury: A teaching manual]. KNTEU, 137 p. (in Ukrainian)

Havrylishyn, A. P., Kozyrieva, V. P. (2007). Funktsii ta zavdannia kaznacheistva deiakykh zarubizhnykh krain [Functions and tasks of the Treasury of some foreign countries]. Yurydychnyi visnyk «Povitriane ta kosmichne pravo» [Legal Bulletin "Aerospace and Space Law"]. 3(4), 61-66. (in Ukrainian)

United Kingdom Government: HM Treasury. Retrieved from https://www.gov.uk/government/organisations/ hm-treasury/about.

Horuzhii, S. (2016). Rozpodil rehulyatornykh i nahlyadovykh funktsii na finansovomu rynku: yevropeiskyi dosvid ta rekomendatsii dlia Ukrainy [Distribution of regulatory and supervisory functions in the financial market: European experience and recommendations for Ukraine]. Ofis $z$ finansovoho ta ekonomichnoho analizu $u$ Verkhovnii Radi Ukrainy (OFEA) [The office for financial and economic analysis in the Verkhovna Rada of Ukraine (OFEA)]. 28 p. (in Ukrainian)

Finansinspektionen: about FI. Retrieved from: http://www.fi.se/en/about-fi/.

Stukalo, N. V., Litvin, M. V., Derkach, M. I. (2014). Hlobalni finansy: hlobalnyi posibnyk [Global Finance: A Global Guide]. Dnepropetrovsk, 1092 p. (in Ukrainian)

Rudenko, Yu. M., Tokar, V. V. (2010). Finansovi systemy zarubizhnykh krain: navchalnyi posibnyk [Financial systems of foreign countries: A teaching manual]. K.: KNEU. 348 p. (in Ukrainian) 